\title{
STUDY ON REMOTE SENSING IMAGE CHARACTERISTICS OF ECOLOGICAL LAND: CASE STUDY OF ORIGINAL ECOLOGICAL LAND IN THE YELLOW RIVER DELTA
}

\author{
G. Q. An ${ }^{1,2, *}$ \\ ${ }^{1}$ Shandong Land Planning and Surveying Institute, 250014 Jinan, Shandong, China - an_tiger_@ 163.com \\ ${ }^{2}$ Shandong Scientific Research Base for Key Laboratory of Land Use Ministry of Land and Resources, 250014 Jinan, Shandong, \\ China-an_tiger_@163.com
}

Commission III, WG III/7

KEY WORDS: Ecological Land, Remote Sensing, Spectral Characteristics, Yellow River Delta, NDVI

\begin{abstract}
:
Takes the Yellow River Delta as an example, this paper studies the characteristics of remote sensing imagery with dominant ecological functional land use types, compares the advantages and disadvantages of different image in interpreting ecological land use, and uses research results to analyse the changing trend of ecological land in the study area in the past 30 years. The main methods include multi-period, different sensor images and different seasonal spectral curves, vegetation index, GIS and data analysis methods. The results show that the main ecological land in the Yellow River Delta included coastal beaches, saline-alkaline lands, and water bodies. These lands have relatively distinct spectral and texture features. The spectral features along the beach show characteristics of absorption in the green band and reflection in the red band. This feature is less affected by the acquisition year, season, and sensor type. Saline-alkali land due to the influence of some saline-alkaline-tolerant plants such as alkali tent, Tamarix and other vegetation, the spectral characteristics have a certain seasonal changes, winter and spring NDVI index is less than the summer and autumn vegetation index. The spectral characteristics of a water body generally decrease rapidly with increasing wavelength, and the reflectance in the red band increases with increasing sediment concentration. In conclusion, according to the spectral characteristics and image texture features of the ecological land in the Yellow River Delta, the accuracy of image interpretation of such ecological land can be improved.
\end{abstract}

\section{INTRODUCTION}

With the construction of 'Ecological Civilization' and the implementation of the 'Beautiful China' strategy, ecological protection has become a subject of widespread concern for scholars. The rapid advancement of industrialization and urbanization has taken up a large amount of land resources. Under the most stringent arable land protection policy in China, the virgin land cultivation has eventually led to a decrease of large area of primary ecological land use, and the original ecological system has been strongly disturbed and destroyed and even disappeared. Especially in the heavily populated and economically developed regions on the eastern coast of China, the land that has not yet been affected by human activities and the ecosystems it carries are running out. The Yellow River Delta is a typical example. Many scholars have researched the investigation, development and utilization of land-use types such as saline-alkaline lands(Guan et al. 2001), costal beach(Chen et al. 2000) in the Yellow River Delta, and some scholars have analysed the spectral characteristics of remote sense data with such lands(Wu et al. 2007; Wu et al. 2012; Zeng et al. 1984). However, the data sources used are relatively simple and the time period is short. It is difficult to reflect the common characteristics of these ecological lands on different sensors and at different time periods. This paper takes the Yellow River Delta as an example, uses a variety of sensor data, observes for a long period of time, sums up the features of remote sensing images of ecological land use in the Yellow River Delta, and compares the strengths and weaknesses of different data. The research results can provide reference for remote sensing monitoring, interpretation and extraction of original ecological land, observation of its changing process and evolution trend, and protection of the original ecological land and ecosystem.

\section{STUDAY AREA}

The Yellow River Delta is located in the North-east of Shandong Province, mainly in Dongying city of Shandong province in China, on the south bank of the Bohai Gulf and the west coast of Laizhou Bay. It is one of the three major delta estuaries in China, and is the most concentrated area for ecological use in Shandong Province. The total land area is $7923 \mathrm{Km}^{2}$, with a total population of 2.13 million. There are mainly three rivers, including the Yellow River, Xiaoqing River, Tuhai River here. In recent years, human activities have a very strong impact on the Yellow River Delta region, and the categories of ecological land have undergone fundamental changes. Among them, wetland, saline-alkali land and waters which have the leading function of ecology and environment have rapidly reduced. To a certain extent, the tendency of ecological land change in the Yellow River Delta reflects the trend of the national ecological land use, especially in the east coast where the economy and society have developed rapidly in recent years. Fig. 1 is the map of study area.

\section{DATA AND METHODS}

\subsection{Data}

The surface reflectance spectrum is affected by many factors such as the type of land use, date, seasonal variation, and weather conditions, and the spectral information obtained by different sensors is also different. Considering these factors,

\footnotetext{
* Corresponding author

This Study is supported by the project of Ecological Land Use and Protection of Shandong
} 
different years, different sensors and different seasons were used to observe the same location to compare and find the spectral characteristics of the same ecological land category. This paper studies the spectral features along the beach, and analyses the saline-alkaline lands and water bodies on the basis of it. For coastal beaches, the same point $\left(119^{\circ} 11^{\prime} 55.46 " \mathrm{E}\right.$, $\left.37^{\circ} 42^{\prime} 40.80^{\prime \prime} \mathrm{N}\right)$ were selected as experimental samples. The main reasons were as follows: 1 . based on the field investigation, the type of land use was coastal beach and it had not changed since 1982, and it was less affected by human activities. 2. The data here is easily accessible, most satellite observations can cover.

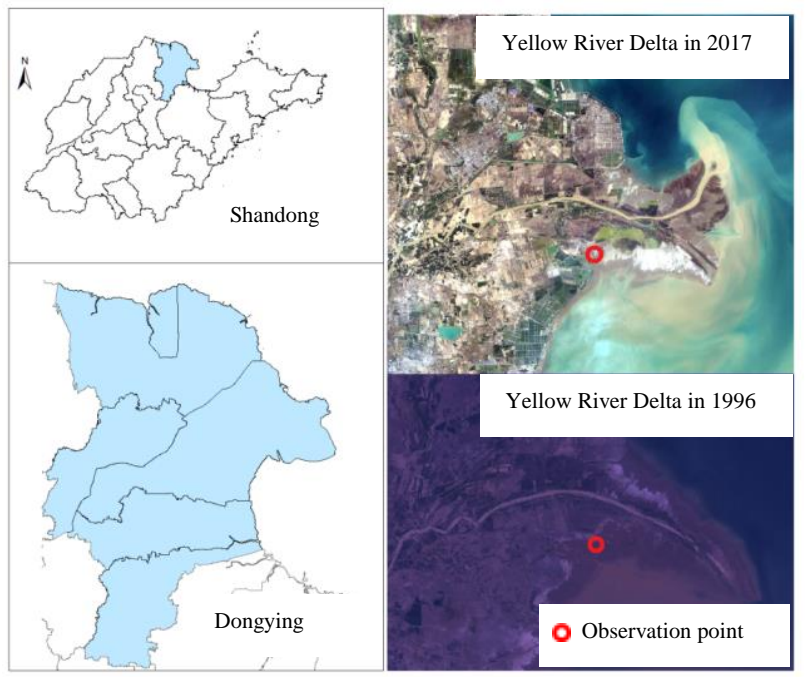

Figure 1 Location of the study area and observation point location on remote sensing imagery

This article mainly uses MSS, TM, ETM, OLI, ALI and Hyperion sensor images as data sources. The data set is provided by Geospatial Data Cloud site, Computer Network Information Centre, Chinese Academy of Sciences, (http://www.gscloud.cn), see as table 1 .

\begin{tabular}{|l|l|}
\hline Sensor & \multicolumn{1}{|c|}{ Date } \\
\hline EO1 ALI & $2012 / 4 / 52012 / 5 / 42012 / 8 / 6$ 2005/4/14 \\
EO1 & \\
Hyperion & $2012 / 4 / 5$ \\
Level 1Gst & \\
Landsat-8OLI & $2016 / 4 / 202017 / 4 / 232017 / 5 / 25$ \\
Landsat- & $2002 / 5 / 242016 / 3 / 11$ \\
7ETM+ & \\
Landsat-4,5 & $1986 / 5 / 201996 / 5 / 152006 / 4 / 9$ \\
TM & $1982 / 4 / 51984 / 6 / 7$ \\
Landsat MSS & Ta \\
\hline
\end{tabular}

Table 1 the mainly image data set table

\subsection{Methods}

3.2.1 Spectral analysis: Using different sensors to observe the same location for the same type of site for many years, it is possible to summarize and discover the spectral characteristics of this type of land use and its multi-year variation, and to analyse the pros and cons of different sensors for information acquisition.

3.2.2 Vegetation index: Using the vegetation index to analyse the vegetation characteristics of the same land in the same place can reflect the degree of vegetation coverage of this kind of land. NDVI was calculated by formula as(Robinson et al. 2017):

$$
N D V I_{i}=\frac{N I R_{i}-R_{i}}{N I R_{i}+R_{i}}
$$

where NDVI $i=$ the $i$-th period Normalized Difference Vegetation Index

NIR $i=$ near infrared band

$\mathrm{R} i=$ red band

3.2.3 Ecological land classification: Based on research results of the classification of ecological land in China by the researcher Longhua Lou(Long et al. 2015) and Professor Wang Jing(Wang et al. 2017), this paper mainly study the original ecology land including coastal beaches, saline-alkaline lands, and water bodies of Yellow River Delta.

\section{THE FEATURES OF REMOTE SENSING IMAGE OF ECOLOGICAL LAND}

\subsection{Coastal beaches}

As a large amount of silt carried by the Yellow River deposits on the Yellow Sea coast, it has formed a wide range of coastal beaches, which have the unique typical ecological functions in the east of China.
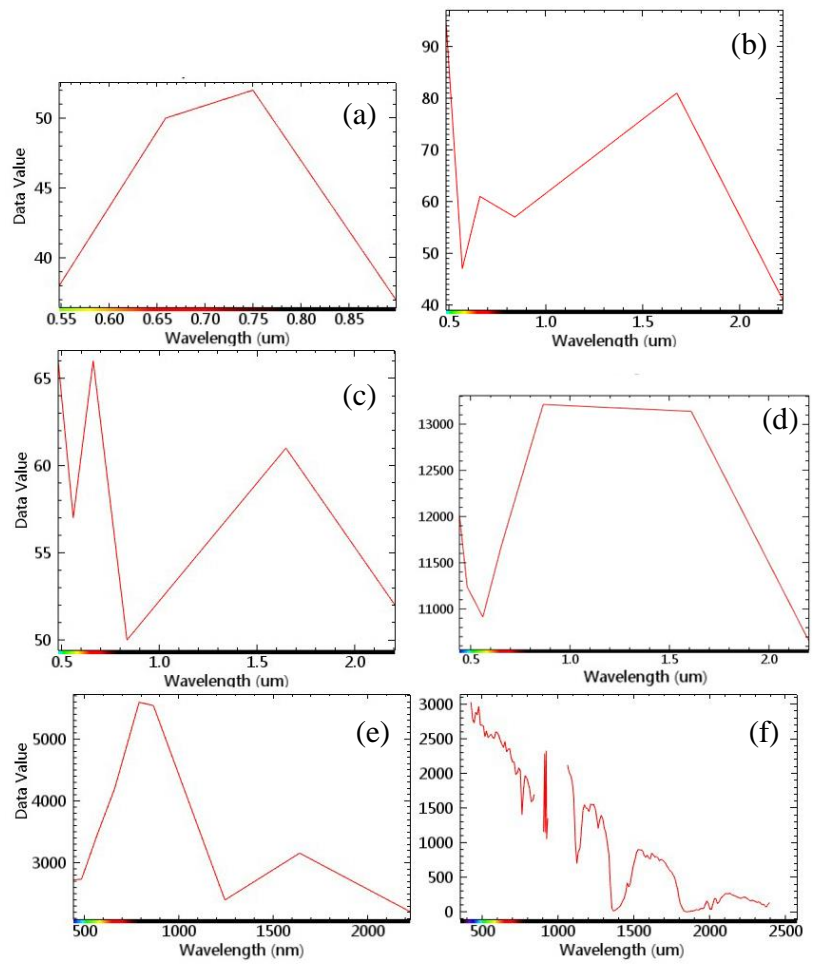

Figure 2 Spectral curves of different sensor images along the beach, where the satellite, sensor type, and acquisition time are as follow: (a)Landsat2 Mss 1982/02/01, (b)Landsat5 TM 1996/05/15， (c)Landsat7 ETM 2016/03/11， (d)Landsat8 OLI

2017/05/25, (e)EO1 ALI 2012/08/06, (f)EO1 Hyperion 2012/04/05

Figure 2 shows the image characteristics of coastal beach in the same location in different years and different sensor remote sensing images. These spectral curves all exhibit a common feature. In the green band (MSS 0.5-0.6 $\mu \mathrm{m}$, TM 0.52-0.60 $\mu \mathrm{m}$, ETM 0.52-0.60 $\mu \mathrm{m}$, OLI 0.53-0.59 $\mu \mathrm{m}$, ALI 0.525-0.605 $\mu \mathrm{m}$, 
and Hyperion 0.569-0.579 $\mu \mathrm{m})$, the reflectance appeared low, followed by a rapid rise. It shows that the absorption of green spectrum is more intense along the beach, while the reflection of the red spectrum is stronger. Judging from the 1982-2017, the evolution of time and seasonal changes did not have much impact on this characteristic of the coastal beach spectrum.

According to many years of different sensor image data, the texture features of the beach are characterized by contiguous coastal distribution, flat terrain, well-developed water systems, and dendritic and flat shapes.

\subsection{Water bodies}

The river system in the Yellow River Delta is well developed and its types are relatively diverse. Among them, the water bodies of original ecological land that are less affected by human activities mainly include rivers and ocean. The analysis of the water body in the Yellow River delta using OLI sensors' images obtained on $2017 / 05 / 05$, which shows that the characteristics exhibited by different bodies of water are slightly different.

Figure 3 shows that the spectral characteristic of the water in the Yellow River delta is that as the wavelength of the light increases, the reflectivity of the water decreases rapidly. However, for the Yellow River and shallow seawater bodies, due to the large amount of sediments, they show high reflectivity in the red and near infrared bands. The rivers are distributed linearly in the Yellow River Delta. The boundary between the water surface and the two banks is obvious and it is easy to interpret.
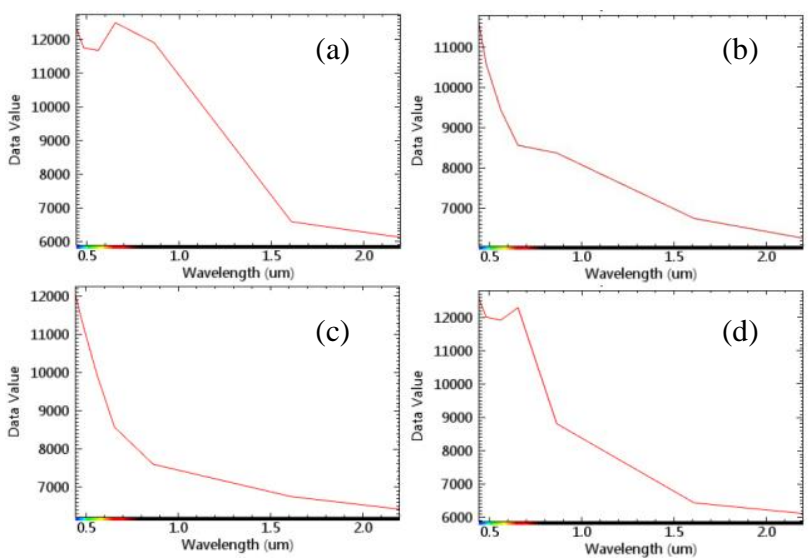

Figure 3 Spectral curves of different water bodies in the OLI sensor image Landsat 8 OLI 2017/05/25, where (a) is the

Yellow River, (b) the general river, (c) the deep sea, (d) the shallow sea

\subsection{Saline-alkaline lands}

The spectral characteristics of the saline-alkali soil were analyzed using OLI sensors for the four seasons of 2016 and 2017. The results are shown in Figure 4. It can be seen that saline-alkali lands absorb strongly in the green band (0.53-0.59) in spring (Fig. 4(a)) and winter (Fig. 4(d)), and the vegetation index is relatively low, 0.08 and 0.07 , respectively. Summer (Fig. 4(a)) and autumn (Fig. 4(d)) have strong absorption in the red band (0.64-0.67) with a higher vegetation index of 0.22 and 0.23 , respectively.

According to the texture features of the image, saline-alkali lands generally show less flocculent patches, less affected by human activities, continuously distributed in a planar pattern with high reflectance of inclusions. The above image characteristics indicate that the spectral characteristics of salinealkali land are greatly influenced by the seasons, which has a certain influence on the interpretation and extraction accuracy of saline-alkali land.
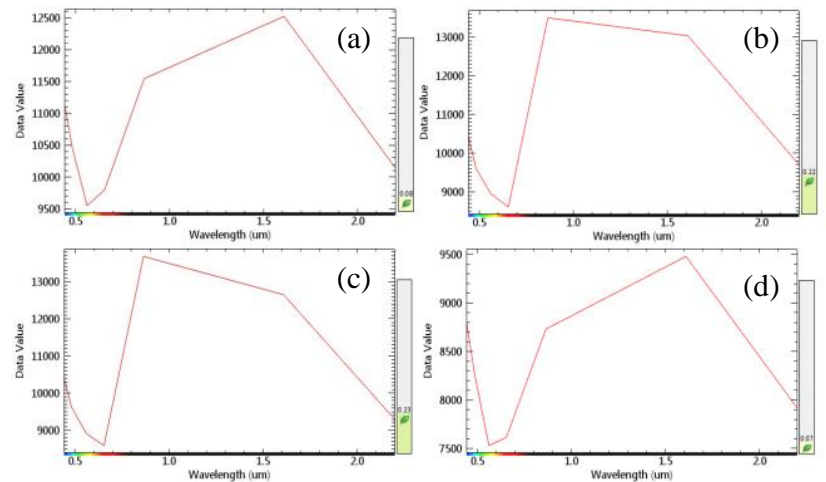

Figure 4 Spectrograms of saline-alkali fields in OLI sensor images in different seasons. (a)Landsat 8 OLI 2016/03/03,(b) Landsat 8 OLI 2017/09/30, (c) Landsat 8 OLI 2016/12/16,(d) Landsat 8 OLI 2017/05/05

\section{FINDINGS}

\subsection{Typical ecological land use has obvious spectral features}

By using multi-periods, multiple sensors and remote sensing images of different seasons, the spectral characteristics of ecological land as coastal beaches, water and saline-alkali land in the Yellow River Delta were analyzed. It can be seen that for a wide distribution, the ecological land with dominant features has obvious spectral characteristics. In addition to the saline characteristics of these ecological lands affected by the season, the spectral characteristics of other ecological lands are relatively stable. The data acquisition period has less impact.

\subsection{Typical ecological land use has obvious image features}

Analysing the data acquired by different sensors and different time periods, it can be seen that the image features of remote sensing images such as coastal beaches and saline-alkali soils are also obvious. The texture features are quite different from other land types and the boundaries are relatively clear.

\section{CONCLUSIONS}

\subsection{Typical ecological land use has obvious image features}

This paper makes use of multi-source remote sensing image data to analyze the ecological land use of the Yellow River Delta, and distinguishes the spectral characteristics and image features of these representative ecological lands. It provides a reference for the interpretation and extraction of remote sensing imagery features from these ecological lands, and enhances the accuracy of computer-based automatic extraction and humancomputer interaction extraction of such ecological lands. 


\subsection{The pro and con of different remote sensing images}

Comprehensive comparison of the six sensor data shows that various types of sensor images have advantages and disadvantages for the extraction of ecological land and the study of the evolution and distribution of ecological land. See Table 2 for details, as show in table 2 .

\subsection{Ecological Land Use Change in the Yellow River Delta}

Using vegetation index, supervised classification and unsupervised classification by GIS and other methods, and comparing the area and distribution of ecological land in the Yellow River Delta in 1982 and 2016, it can be seen that the total area of ecological land in the Yellow River Delta has continued to decrease over the past 30 years.

\begin{tabular}{|c|c|c|c|c|c|}
\hline $\begin{array}{c}\text { Sensor } \\
\text { Type }\end{array}$ & $\begin{array}{c}\text { Spatial } \\
\text { Resolution }\end{array}$ & $\begin{array}{c}\text { Spectral } \\
\text { Resolution }\end{array}$ & $\begin{array}{l}\text { Single Scene } \\
\text { Coverage }\end{array}$ & $\begin{array}{l}\text { Acquisition } \\
\text { Difficulty }\end{array}$ & Historical Data \\
\hline E01 ALI & $\begin{array}{l}30 \mathrm{~m} \text {, easy to } \\
\text { interpret }\end{array}$ & $\begin{array}{l}10 \text { bands with } \\
\text { obvious spectral } \\
\text { features }\end{array}$ & $\begin{array}{l}\text { Wide coverage, } \\
\text { conducive to regional } \\
\text { spatial extraction }\end{array}$ & $\begin{array}{l}\text { Easy access } \\
\text { to different } \\
\text { seasons }\end{array}$ & $\begin{array}{l}\text { 2001-2014, conducive to the } \\
\text { formation of data series after } 2000\end{array}$ \\
\hline $\begin{array}{l}\text { E01 ALI } \\
\text { Level } \\
\text { 1Gst }\end{array}$ & $\begin{array}{l}30 \mathrm{~m} \text {, easy to } \\
\text { interpret }\end{array}$ & $\begin{array}{l}242 \text { bands with } \\
\text { obvious spectral } \\
\text { features }\end{array}$ & $\begin{array}{l}\text { Small coverage, not } \\
\text { conducive to regional } \\
\text { spatial extraction }\end{array}$ & $\begin{array}{l}\text { Not easy to } \\
\text { get } \\
\text { different } \\
\text { season data }\end{array}$ & $\begin{array}{l}2001-2014 \text {, it is difficult to form } \\
\text { long-term serial data }\end{array}$ \\
\hline $\begin{array}{l}\text { Landsat- } \\
\text { 80LI }\end{array}$ & $\begin{array}{l}15 \mathrm{~m}, 30 \mathrm{~m}, 100 \mathrm{~m} \\
\text { easy to } \\
\text { interpret }\end{array}$ & $\begin{array}{l}11 \text { bands with } \\
\text { obvious spectral } \\
\text { features }\end{array}$ & $\begin{array}{l}\text { Wide coverage, } \\
\text { conducive to regional } \\
\text { spatial extraction }\end{array}$ & $\begin{array}{l}\text { Easy access } \\
\text { to different } \\
\text { seasons }\end{array}$ & $\begin{array}{l}\text { 2013-2017, the time series data is } \\
\text { shorter }\end{array}$ \\
\hline $\begin{array}{l}\text { Landsat- } \\
7 \mathrm{ETM}^{+}\end{array}$ & $\begin{array}{lr}15 \mathrm{~m}, & 30 \mathrm{~m}, \\
\text { easy } & \text { to } \\
\text { interpret } & \end{array}$ & $\begin{array}{l}8 \text { bands with } \\
\text { obvious spectral } \\
\text { features }\end{array}$ & $\begin{array}{l}\text { Wide coverage, } \\
\text { conducive to regional } \\
\text { spatial extraction }\end{array}$ & $\begin{array}{l}\text { Easy access } \\
\text { to different } \\
\text { seasons }\end{array}$ & $\begin{array}{l}\text { 1999-2017, long-term serial data can } \\
\text { be formed, which is conducive to the } \\
\text { study of the historical evolution of } \\
\text { ecological land use. }\end{array}$ \\
\hline $\begin{array}{l}\text { Landsat- } \\
4,5 \mathrm{TM}\end{array}$ & $\begin{array}{l}30 \mathrm{~m} \text {, easy to } \\
\text { interpret }\end{array}$ & $\begin{array}{l}7 \text { bands with } \\
\text { obvious spectral } \\
\text { features }\end{array}$ & $\begin{array}{l}\text { Wide coverage, } \\
\text { conducive to regional } \\
\text { spatial extraction }\end{array}$ & $\begin{array}{l}\text { Easy access } \\
\text { to different } \\
\text { seasons }\end{array}$ & $\begin{array}{l}\text { 1982-2011, long-term sequence data } \\
\text { can be formed, which is conducive to } \\
\text { the study of the historical evolution } \\
\text { of ecological land use. }\end{array}$ \\
\hline $\begin{array}{l}\text { Landsat } \\
\text { MSS }\end{array}$ & $\begin{array}{l}60 \mathrm{~m}, \\
\text { difficult to } \\
\text { interpret }\end{array}$ & $\begin{array}{l}4 \text { bands with not } \\
\text { obvious spectral } \\
\text { features }\end{array}$ & $\begin{array}{l}\text { Wide coverage, } \\
\text { conducive to regional } \\
\text { spatial extraction }\end{array}$ & $\begin{array}{l}\text { Easy access } \\
\text { to different } \\
\text { seasons }\end{array}$ & $\begin{array}{l}\text { 1972-1992, long-term sequence data } \\
\text { can be formed, which is conducive to } \\
\text { the study of the historical evolution } \\
\text { of ecological land use }\end{array}$ \\
\hline
\end{tabular}

Table 2 The pros and cons of various types of sensor data

\section{REFERENCES}

Guan Y.X., Liu G.H., Liu Q.S., Ye Q.H., 2001. The study of salt-affected soils in the Yellow River Delta based on remote sensing. Journal of Remote Sensing, 5(1),pp.46-52.

Chen H.L., Xiao S.J., Cheng Y.J., Wang M., 2000. Study of the exploitation and utilization of the yellow river delta tidal flat resources . Coast Engineering, 2000(4), pp.59-64.

Wu H.S., Liu Z.L., 2007. Remote Sensing and Mapping of Saline Sodic Land Based on Spectral Characteristics for Da'an City. System Sciences and Comprehensive Studies in Agriculture, 23(2), pp.178-182.

Wu D.D., 2012. The Application of RS Technology in The Extraction of coastal beach. Geometrics \& Spatial information technology, 35(11), pp. 83-84.

Zeng Q.Z., Cao M.S., Feng X.Z., Liang F.X., Chen X.Z., Sheng W.K., 1984. Spectral Reflectance Characteristics of Ice, Snow and Water in Northwest China. Chinese Science, 14(4), pp. $370-377$.

Robinson N.P., Allred B.W., Jones M.O., Moreno A., Kimball J.S., Naugle D.E., Erickson T.A., Richardson A.D., 2017. A Dynamic Landsat Derived Normalized Difference Vegetation
Index (NDVI) Product for the Conterminous United States. Remote Sensing, 9(863).

Long H.L., Liu Y.Q., Li T.T., Wang J., Liu A.X., 2015. Preliminary Study on the Classification of Ecological Land .Chinese Journal of Eco-Environment, 2015(1), pp. 1-7.

Wang J., Wang W., Qi Y., He T., Wu R.J., Chen Y.Y., 2017. Classification System and Spatio-temporal Distribution of Ecological Land in China in the Period of 1996-2012. Geographical Research (Geogr Res), 36 (3) , pp. 453-470. 